two dictionaries.' In M. Markus, C. Upton \& R. Heuberger (eds), Joseph Wright's English Dialect Dictionary and Beyond. Frankfurt am Main: Peter Lang, pp. 201-18.

—. 2010b. 'Assessing non-standard writing in lexicography.' In Raymond Hickey (ed.), Varieties in Writing: The Written Word as Linguistic Evidence. Amsterdam: John Benjamins, pp. 43-60.

The English Dialect Dictionary, 1898-1905. Ed. Joseph A. Wright. London: Henry Frowde (at the expense of Joseph Wright); subsequently Oxford: Oxford University Press.

Geeraerts, D. 2010a. 'Lexical variation in space.' In P. Auer \& J. E. Schmidt (eds), Language and Space: Theories and Methods: an International Handbook of Linguistic Variation. Handbooks of Linguistics and Communication Science 30.1. Berlin: Walter de Gruyter, pp. 821-36.

—. 2010b. Theories of Lexical Semantics. Oxford: Oxford University Press.

Hanks, P. 2000. 'Do word meanings exist?' Computers and the Humanities, 34, 205-11.

Kilgarriff, A. 1997. 'I don't believe in word senses.' Computers and the Humanities, 31, 91-113.

Labov, W. 1972. Sociolinguistic Patterns. Philadelphia: University of Pennsylvania Press.

Mugglestone, L. 2003. Talking Proper: The Rise of Accent as Social Symbol. 2nd edition. Oxford: Oxford University Press.
The Oxford English Dictionary, 1884-1928. Ed. Sir James A. H. Murray, Henry Bradley, Sir William A. Craigie and Charles T. Onions. Supplement and Bibliography 1933. Supplement, 1972-1986; ed. Robert W. Burchfield. 2nd edition, 1989; ed. John A. Simpson and Edmund

S. C. Weiner. Additions Series, 1993-7; ed. John A. Simpson, Edmund S. C. Weiner and Michael Proffitt. 3 rd edition (in progress) OED Online, March 2000-, ed. John A. Simpson, www.oed.com [=OED]

Robinson, J. A. 2010a. 'Awesome insights into semantic variation.' In D. Geeraerts, G. Kristiansen \& Y. Piersman (eds), Advances in Cognitive Sociolinguistics. Berlin: Mouton de Gruyter, pp. 85-110.

—. 2010b. 'Semantic variation and change in present-day English.' Unpublished PhD Dissertation. The University of Sheffield. Available via http://etheses.whiterose.ac.uk/ 2232/.

—. 2011. 'A sociolinguistic perspective on semantic change.' In K. Allan \& J. Robinson (eds), Current Methods in Historical Semantics. Mouton De Gruyter: Berlin, pp. 199-231.

Sebba, M. 2007. Spelling and Society: The Culture and Politics of Orthography Around the World. Cambridge: Cambridge University Press.

Traugott, E. C. \& Dasher, R. B. 2002. Regularity in Semantic Change. Cambridge: Cambridge University Press.

[Paperback ed. wrongly dates original publication as 2005.]

\title{
Exploring pronunciation features of Yunnan English - CORRIGENDA
}

\author{
RAN AO AND EE LING LOW
}

doi:10.1017/S0266078412000284, Published by Cambridge University Press, [September 2012].

In Ao \& Low (2012: 27-33) the following corrections should be made:

Page 29, Column 1, last line: For Northwest read Southwest

Page 30, Table 2, Speaker 7, 'Place of Origin': For Simao read Pu'er

\section{Reference}

Ao, R. \& Low, E. L. 2012. 'Exploring pronunciation features of Yunnan English.’ English Today, 28(3), 27-33. 